\title{
The efficacy of chloroquine treatment against naturally occuring Giardia duodenalis infection in lambs
}

\section{La eficacia del tratamiento de cloroquina contra la infección natural por Giardia duodenalis en corderos}

\author{
Umit Karademir, ${ }^{1 *}$ Ph.D, Kerem Ural, ${ }^{2}$ Ph.D, Nuran Aysul, ${ }^{3}$ Ph.D, Adnan Ayan, ${ }^{3}$ DVM, \\ Songul Toplu, ${ }^{2}$ DVM, Onur Ortlek, ${ }^{2}$ DVM, Canberk Balıkci, ${ }^{2}$ DVM, Ahmet Kunyeli, ${ }^{2}$ DVM, \\ Hasan Erdogan, 2 Ph.D
}

\begin{abstract}
${ }^{1}$ Adnan Menderes University, Faculty of Veterinary Medicine, Department of Pharmacology and Toxicology, Isikli, Aydin, Turkey. ${ }^{2}$ Adnan Menderes University, Faculty of Veterinary Medicine, Department of Internal Medicine, Isikli, Aydin, Turkey. ${ }^{3}$ Adnan Menderes University, Faculty of Veterinary Medicine, Department of Parasitology, Isikli, Aydin, Turkey. *Correspondence: umitkarademir@yahoo.com Cell Phone +0905054544798
\end{abstract}

Received: May 2015; Accepted: October2015.

\begin{abstract}
Objective. The aim of the present study was to determine the efficacy of Chloroquine (Cq), an antimalarial medicine, administered at a dose of $2.5 \mathrm{mg} / \mathrm{kg}$, orally, during 5 consecutive days, in Sakiz and Merino lambs naturally infected with Giardia duodenalis. Materials and methods. To this extent weaned 10 weeks of aged lambs were enrolled and randomly assigned into two groups based on treatment (group $\mathrm{C}, \mathrm{n}=18$ lambs treated with $\mathrm{Cq}$ ) and placebo (group $\mathrm{P}, \mathrm{n}=8$ untreated control animals). Diagnosis was based on detection of trophozoit and/or cysts on fecal flotation. Cyst count per gram feces (days 0, 3, 7 and 10) was analyzed among groups. Results. During the trial, regarding the efficacy of $\mathrm{Cq}$ on days 3., 7., and 10. There was significant $(p<0.01)$ reduction in cyst excretion; whereas evaluation of mean geometric cyst excretion revealed $100 \%$ reduction. Conclusions. There was a very high (100\%) reduction in cyst excretion in the Cq treatment group compared to the positive untreated control group on days 3,7 and 10 , resulting in a significant $(p<0.001)$ reduction, making $\mathrm{Cq}$, safety, and thus highly effective treatment option of lambs with naturally occuring giardiasis.
\end{abstract}

Key words: Giardia duodenalis, chloroquine, lamb (Source: $C A B$ ).

\section{RESUMEN}

Objetivo. El objetivo del presente estudio fue determinar la eficacia de la cloroquina, un medicamento contra la malaria, administrado a una dosis de $2.5 \mathrm{mg} / \mathrm{kg}$, por vía oral, durante 5 días consecutivos, en Corderos Sakiz y Merino infectados naturalmente con Giardia duodenalis. Materiales y metodos. En esta medida destetados 10 semanas de edad fueron incluidos y asignados al azar en dos grupos sobre la base del tratamiento (grupo $\mathrm{C}, \mathrm{n}=18$ corderos tratados con cloroquina) y placebo (grupo $\mathrm{P}, \mathrm{n}=8$ animales de control no tratados). El diagnóstico se basa en la detección de trophozoit y/o quistes en la flotación fecal. Quiste recuento por gramo de heces (día 0, 3, 7 y 10) se analizó entre los grupos. Resultados. Respecto a la eficacia de la cloroquina en los días 3,7 y 10 existió una reducción significativa $(p<0.01)$ en la excreción de quistes; mientras que la evaluación de la media de la excreción 
de quistes reveló una reducción del 100\%. Conclusiones. Durante el estudio hubo una reducción del $100 \%$ en la excreción de quistes en el grupo de tratamiento con cloroquina en comparación con el grupo control no tratado positivo en los días 3,7 y 10, lo que resulta en una disminución significativa $(p<0.001)$ por lo que la cloroquina razonablemente es una opción de tratamiento por el costo, seguridad, y por lo tanto muy eficaz de corderos infectados naturalmente con giardiasis.

Palabras Clave: Giardia duodenalis, cloroquina, cordero (Fuente: CAB).

\section{INTRODUCTION}

The genera Giardia has been described as an important enteropathogen in various species of domesticated animals and humans, and several researches in ruminants have been carried out in an attempt to detect prevalence rates in livestock $(1,2)$. Moreover Giardia duodenalis ( $G$. lamblia and $G$. intestinalis) has been emerged as a significant parasite in domestic ruminants in relation to high levels of infection. Reagarding latter animals, the typical feature of infection is a peak cyst shedding at between 5-10 weeks of age (3). Furthermore giardiasis has a significant pathogenic role in livestock with diarrhoea, weight loss, lethargy and poor condition as presenting clinical signs $(4,5)$. Besides giardiasis in sheep, is of public health concern, in relation to contamination of surface and ground waters through pasture and naturally acquired episodes of contamination by water or food (4). In Turkey prevalence rates as $36.6 \%(6)$ and $48.48 \%$ (7) were reported previously.

Although not evidenced, sheep flocks are considered as a potential threat for contaminating water supplies (8). Small ruminants, i.e. sheep may be considered as reservoir for human infections $(8,9)$. All infected animals with giardiasis might therefore be treated due to probable source of infection for humans or other animals (10).

Currently none of the drugs is licensed or FDA approved for the treatment of giardiasis in sheep. The traditional anti-Giardial treatment in sheep includes the usage of fenbendazole $(10,11)$, albendazole $(12)$, secnidazol $(13,14)$ and paromomycin (15) resulting in a clinical benefit in treated lambs. Contrarily fenbendazole and albendazole need to be adminestered in multiple doses, besides paramomycin is expensive. Related literature on the efficacy of antigiardial treatment in sheep involves limited and aforementioned studies. Taking into account cases refractory to traditional treatment, there is still a need to establish reasonably priced and novel therapeutic protocols. $\mathrm{Cq}$ is a reasonably priced, actually cheap compound used as antimalarial $(16,17)$, against Entamoeba histolytica (16) and in the control of some chronic inflammatory conditions (18), but its usage

\section{INTRODUCCIÓN}

El género Giardia se describe como un importante enteropatógeno en diversas especies de animales domésticos y humanos y se han realizado varias investigaciones en rumiantes en un intento por detectar las tasas de prevalencia en el ganado $(1,2)$. Además la Giardia duodenalis (G. lamblia y $G$. intestinalis) se ha convertido en un parásito significativo en rumiantes domésticos en relación con altos niveles de infección. Con respecto a estos últimos animales, la característica típica de la infección es un quiste que presenta su pico entre las 5-10 semanas de edad (3). Además la giardiasis tiene un papel patogénico importante en animales que presentan síntomas clínicos tales como la diarrea, pérdida de peso, letargo y una condición pobre $(4,5)$. Además la giardiasis en los ovinos es motivo de preocupación en salud pública debido a la contaminación de las aguas superficiales y aguas subterráneas a través del pasto y a episodios de contaminación adquiridos naturalmente a través del agua o de los alimentos (4). En Turquía se divulgaron previamente tasas de prevalencia del $36.6 \%$ (6) y $48.48 \%$ (7).

Aun cuando no hay evidencia, los rebaños de ovejas se consideran como una amenaza potencial de contaminación de los suministros de agua (8). Pequeños rumiantes, como las ovejas, pueden considerarse reservorio de infecciones humanas $(8,9)$. Todos los animales infectados con giardiasis pueden tratarse, por tanto, debido a que son fuente probable de infección para los seres humanos u otros animales (10).

Actualmente ningún medicamento tiene licencia o está aprobado por la FDA para el tratamiento de la giardiasis en las ovejas. El tratamiento tradicional anti-giardial en ovejas incluye el uso de fenbendazol $(10,11)$, albendazol (12), secnidazol $(13,14)$ y paromomicina $(15)$ lo que resulta en un beneficio clínico para los corderos tratados. Por el contrario, el fenbendazol y el albendazol tienen que administrarse en dosis múltiples, mientras que la paramomicina es costosa. Literatura relacionada sobre la eficacia del tratamiento anti-giardial atribuible a ovejas implica estudios limitados mencionados anteriormente. Teniendo en cuenta casos refractarios al tratamiento tradicional, aún es necesario establecer protocolos terapéuticos 
against giardiasis is still under investigation. The activity of $\mathrm{Cq}$ or other 4-aminoquinolines is related to their binding to haematin within the monomeric/dimeric forms, subsequnetly inhibition of haemozoin formation and resulting in parasite death (19). The effect of chloroquine against intestinal parasites has received less attention; besides it remains unclear how $\mathrm{Cq}$ treatment helps generate strong and durable immune response. Therefore the purpose of this study was to evaluate the efficacy of $\mathrm{Cq}$ in lambs naturally infected with $G$. duodenalis.

\section{MATERIALS AND METHODS}

Animals and housing. 27 lambs at the age of 10 weeks were enrolled, in which they were group housed on Adnan Menderes University, Faculty of Veterinary, Research Farm. The herd was composed of Merino and Sakiz lambs. During the allocation period (10 days) all lambs were screened twice with a 10 days interval to confirm the presence/absence of $G$. duodenalis cysts in the faeces. Prior to trial all lambs were treated with toltrazuril (Cevazuril ${ }^{\circledR}$ Ceva-Vet, $20 \mathrm{mg} / \mathrm{kg}$ bodyweight) for preventing coccidiosis. Individual boxes were cleaned and disinfected with a commercially available quaternary ammonium product for prevention of environmental contamination. Strict preventive measures were taken against contamination between groups. Animals were fed with commerciallly available lamb flakes. Water and hay was provided ad libitum during the study period. All necessary ethical guidelines were taken into consideration for randomized enrollment into the groups. The study protocol was approved by the institutional laboratory animals ethics committee of Adnan Menderes University HADYEK (with no: $64583101 / 2015 / 088$ ) and informed written consent was obtained from all of the lamb owners prior to enrolment of the animals participating in study.

Twenty-six Sakiz lambs at the age of 10 weeks, of both sexes, that tested microscopically positive for giardiasis, were allocated into two groups. Eighteen lambs were randomly assigned to the Cq treatment group (group $\mathrm{C}$ ). The reamining lambs $(n=8)$ were enrolled in positive control group (group P), receiving the latter drug (Kutlu tablet ${ }^{\circledR}$, Keymen İlaç San. ve Tic. Ltd.Şti. 250 $\mathrm{mg}$ ) at a dosage of $2.5 \mathrm{mg} / \mathrm{kg}$ perorally for 5 consecutive days. Due to commercial value of the lambs and ethical concerns only a limited number of cases were enrolled as controls. razonablemente económicos y novedosos. La Cq es un compuesto que tiene un precio razonable, en realidad barato, que se utiliza contra la malaria $(16,17)$, contra la Entamoeba histolytica $(16)$ y en el control de algunas condiciones inflamatorias crónicas (18), pero su uso contra la giardiasis está todavía bajo investigación. La actividad de la Cq o de las otras 4-aminoquinolinas está relacionada con su vínculo a la hematina dentro de las formas monoméricas / diméricas, la posterior inhibición de la formación de hemozoína y que da como resultado la muerte del parásito (19). El efecto de la cloroquina contra los parásitos intestinales ha recibido menos atención; además no queda claro cómo el tratamiento con la $\mathrm{Cq}$ ayuda a generar una respuesta inmune fuerte y durable. Por esta razón el propósito de este estudio fue evaluar la eficacia de la Cq en corderos infectados naturalmente con G. duodenalis.

\section{MATERIALES Y MÉTODOS}

Animales y alojamientos. Se seleccionaron 27 corderos de 10 semanas de edad que estaban alojados en grupo en la Universidad Adnan Menderes, Facultad de Veterinaria, Granja de Investigación. El rebaño estaba compuesto por corderos Merino y Sakiz. Durante el periodo asignado (10 días) se evaluaron todos los corderos dos veces con un intervalo de 10 días para confirmar la presencia / ausencia de quistes de G. duodenalis en las heces. Antes del ensayo los corderos fueron tratados con toltrazuril (Cevazuril ${ }^{\circledR}$ Ceva-Vet, $20 \mathrm{mg} / \mathrm{kg}$ de peso) para la prevención de la coccidiosis. Se limpiaron y desinfectaron cajas individuales con un producto de amonio cuaternario comercialmente disponible para prevenir la contaminación del medio ambiente. Se tomaron estrictas medidas de prevención para evitar la contaminación entre los grupos. Los animales se alimentaron con hojuelas para cordero disponibles comercialmente. El agua y el heno se suministraron ad libitum durante el período de estudio. Se tuvieron en cuenta todas las recomendaciones éticas necesarias para la selección al azar en los grupos. El protocolo de estudio fue aprobado por el Comité de Ética Animal del Laboratorio Institucional de la Universidad Adnan Menderes HADYEK (con No: 64583101/2015/088) y se obtuvo consentimiento por escrito de todos los propietarios de los corderos antes de la selección de los animales a estudiar.

Se distribuyeron en dos grupos los 26 corderos Sakiz de ambos sexos con edad de 10 semanas, que dieron positivo microscópicamente para giardiasis. Dieciocho corderos fueron asignados aleatoriamente al grupo de tratamiento con 


\section{Study design}

Fecal flotation and microscopic examination of fecal samples. Pretreatment day 0 (D0) was designed as the initial treatment of the trial. Collections from each lamb were obtained on 4 occasions and were designated either D0 (before treatment), D3, D7 and D10 after treatment. Fecal samples approximately weighing $5 \mathrm{~g}$ were collected on all occasions manually from the rectum of all lambs involved on each occasion and were submitted immediately to laboratory for fecal flotation. Fecal material was mixed through fifteen $\mathrm{mL}$ of $\mathrm{ZnSO}_{4}$ solution (33\%) and strained onto centrifuge tubes. Afterwards sample was subjected to centrifuge at $880 \times \mathrm{g}$ for 5 minutes as described (20), and to those of similarly to what have been reported elsewhere (14). Following centrifugation, a limited portion of the fecal mixture was collected and emitted on a microscope slide containing Lugol iodine, which was covered by a slip. The slide was then microscopically examined under 40x power for detection of Giardia spp. cysts. The latter procedure was repeated for 2 times from different samples belonging to each lamb collected on day 0 by a single blinded researcher. An involvement criterion was mono infection with G. duodenalis, proved by microscopical fecal samples as reported previously (21).

Assessment of efficacy of treatment. $\mathrm{Cq}$ treatment efficacy in the present study was assessed by microscopic examination of fecal samples collected on D0, D3, D7 and D10 (after treatment completion) and measured based on the reduction in cyst excretion for treatment group in comparsion to the control group. The reduction in cyst excretion was calculated using the HendersonTilton formula, involving geometric mean cyst counts similar to those of Geurden et al (10):

\section{$100 \times[1-(\mathrm{Ta} \times \mathrm{Cb}) /(\mathrm{Tb} \times \mathrm{Ca})]$}

$\mathrm{Ta}$ and $\mathrm{Tb}$; represented the geometric mean cyst count in the Cq treatment group before and after treatment, respectively; where as $\mathrm{Ca}$ and $\mathrm{Cb}$; the geometric mean cyst count in the positive control animals before and after.

The Henderson-Tilton formula is considered as the most appropriate method as described and used previously by Geurden et al (10).

Statistical analysis. The measurements for the number of oocytes were tabulated above the descriptive statistics. Summarized data were presented as geometric and arithmetic mean values. The parameters were not normally distributed after the normality tests and logarithmic transmissions. Then statistical analyses were done
Cq (grupo C). Los corderos restantes $(n=8)$ se incluyeron en el grupo de control positivo (grupo $\mathrm{P})$, recibiendo el último fármaco (tablet ${ }^{\circledR}$ Kutlu, Keymen ILAC San. Ve Tic. Ltd.Şti. 250 mg) con una dosis de $2,5 \mathrm{mg} / \mathrm{kg}$ por vía oral durante 5 días consecutivos. Debido al valor comercial de los corderos y a las preocupaciones éticas se seleccionó sólo un número limitado de casos como control.

\section{Diseño del estudio \\ Flotación fecal y examen microscópico de} las muestras fecales. El pre tratamiento del día 0 (D0) se diseñó como el tratamiento inicial de la prueba. Se obtuvieron muestras de cada cordero en 4 ocasiones y se designaron como D0 (antes del tratamiento) y D3, D7 y D10 después del tratamiento. Las muestras fecales de aproximadamente $5 \mathrm{~g}$ de peso se recolectaron siempre de forma manual del recto de los corderos involucrados y se entregaron inmediatamente al laboratorio para la flotación fecal. La materia fecal se mezcló con quince $\mathrm{ml}$ de solución de ZnSO4 (33\%) y se filtró en tubos de centrífuga. Después la muestra se sometió a centrifugación a $880 \times$ g durante 5 minutos como se describe (20) y de manera similar a lo que se han reportado en otra parte (14). Después de la centrifugación se recogió una parte pequeña de la mezcla fecal y se llevó al portaobjetos de un microscopio que contienen yodo Lugol que estaba cubierta. El portaobjetos se examina microscópicamente con un aumento 40x para detectar los quistes de Giardia spp. El último procedimiento se repitió 2 veces a diferentes muestras pertenecientes a cada cordero recogidas en el día 0 por un único investigador a ciegas o "blinded". Un criterio de participación fue la mono-infección con $G$. duodenalis, comprobada por las muestras fecales microscópicas tal como se reportó anteriormente (21).

Evaluación de la eficacia del tratamiento. La eficacia del tratamiento $\mathrm{Cq}$ en el presente estudio se evaluó mediante el examen microscópico de las muestras fecales recogidas en D0, D3, D7 y D10 (después de la finalizar el tratamiento) y medida en base a la reducción de la excreción de quistes para el grupo de tratamiento en comparación con el grupo control. La reducción en la excreción de quiste se calculó utilizando la fórmula de Henderson-Tilton, que involucra la media geométrica del conteo de quistes, similar a la de Geurden et al (10):

$100 \times[1-(\mathrm{Ta} \times \mathrm{Cb}) /(\mathrm{Tb} \times \mathrm{Ca})]$

Ta y Tb representan la media geométrica del conteo de quistes en el grupo de tratamiento con $\mathrm{Cq}$ antes y después del tratamiento respectivamente; Ca y 
with non-parametric Mann-Whitney $U$ test and probability $(p<0.05)$ was considered to indicate a significant difference. Software package (SPSS ver. 22.0 for Windows - SPSS Inc., Chicago USA) were used for all tests.

\section{RESULTS}

Animal management and treatment applications. No observable and significant adverse reactions to $\mathrm{Cq}$ treatment were noticed in the present study. All lambs had clinical signs compatible with naturally occuring giardiasis, involving diarrhea. No coccidosis nor Cryptosporidium infections were found in any of the lambs enrolled during the study period.

Cyst excretion. The results of the cyst counts were presented in table 1 . Throughout the study period, lambs in control group $P$ remained positive, presenting cyst exceretion on day 10 (ranged 4039.000 ) compared to the initial values (ranged 11000-560.000). On day 10, after Cq treatment, the percentage reduction in cyst excretion calculated based on geometric mean was very high as $100 \%$ on days, 3, 7, and 10 . For group C geometric mean for cyst excretion was significantly decreased $(p<0.001)$ on days 7 and 10 after treatment.

Overall, the efficacy of Cq was $100 \%$ on days 7 and 10 , regardless of the use of arithmetic or geometric mean cyst counts for calculation (Table 1 ).

Table 1. The Giardia duodenalis cyst excretion in the control (Group P) and in the Cq treated (Group C) groups at each sampling day (before treatment [day 0] and D3, D7 and D10 after treatment): the geometric mean (geomean) $\left(\mathrm{X}_{G}\right)$ and arithmetic mean (arith mean) were presented and the percentage reduction calculated based on geometric and arthmetic means. The values at day 0 were cyst excretion prior to treatment.

\begin{tabular}{ccccc}
\hline Geo mean & D0 & D3 & D7 & D10 \\
\hline Group P & 42426.10 & 22684.98 & 11073.64 & 3696.04 \\
Group C & 51369,33 & 0 & 0 & 0 \\
p value & 0.561 & 0.106 & 0.000 & 0.000 \\
Red geomean (\%) & & $100 \%$ & $100 \%$ & $100 \%$ \\
Arithmetic mean & & & & \\
Group P & 92838.89 & 39000.00 & 20650.00 & 13743.33 \\
Group C & 96736.11 & 49577.78 & 1769.44 & 888.89 \\
Red artih mean (\%) & & $75 \%$ & $100 \%$ & $100 \%$ \\
\hline
\end{tabular}

Cb corresponden a la media geométrica del conteo de quistes en los animales de control positivo antes y después.

La fórmula de Henderson-Tilton se considera como el método más apropiado tal como lo describió y utilizó previamente Geurden et al (10).

Análisis estadístico. Las mediciones del número de oocitos se tabularon por encima de la estadística descriptiva. Se presentaron datos resumidos como valores de medias geométrica y aritmética. Los parámetros no tuvieron una distribución normal después de las pruebas de normalidad y transmisiones logarítmicas. Los análisis estadísticos se realizaron con la prueba no paramétrica de Mann-Whitney y la probabilidad $(p<0.05)$ se consideró para indicar una diferencia significativa. En todas las pruebas se utilizó el paquete de software SPSS versión 22.0 para Windows - SPSS Inc., Chicago E.E. U.U.

\section{RESULTADOS}

Gestión animal y aplicaciones de tratamiento. En el presente estudio no se percibieron reacciones adversas observables y significativas en el tratamiento con $\mathrm{Cq}$. Todos los corderos tenían síntomas clínicos compatibles con la giardiasis de origen natural, lo que implicaba diarrea. No se encontraron infecciones con coccidosis ni con Cryptosporidium en ninguno de los corderos involucrados durante el período de estudio.

Excreción de quistes. Los resultados de los conteos de quistes se presentan en la tabla 1. Durante el período de estudio los corderos del grupo de control P siguieron siendo positivos, presentando excreción de quistes el día 10 (en un rango de 40 hasta 39.000) en comparación con los valores iniciales (oscilaron entre 11.000-560.000). El día 10 después del tratamiento con $\mathrm{Cq}$, el porcentaje de reducción de la excreción de quistes calculado con base a la media geométrica era muy alto como el $100 \%$ en los días, 3, 7 y 10 . Para el grupo $\mathrm{C}$ la media geométrica para la excreción de quistes se redujo significativamente $(p<0.001)$ en los días 7 y 10 después del tratamiento.

En general la eficacia de la Cq fue del $100 \%$ en los días 7 y 10 , sin tener en cuenta el uso de la media aritmética o geométrica para calcular el conteo de los quistes (Tabla 1).

\section{DISCUSIÓN}

Según la información de los presentes autores se demostró por primera vez la alta eficacia de un tratamiento oral con Cq de 2.5 mg / kg contra la giardiasis de origen natural en los corderos. En 


\section{DISCUSSION}

To the present authors' knowledge the high efficacy of an oral treatment with Cq at $2.5 \mathrm{mg} /$ $\mathrm{kg}$ against naturally occuring giardiasis in lambs has been demonstrated for the first time. In the present clinical trial, chloroquine was well tolerated, no side effects were evident, thus did not require treatment intervention or withdrawal. Available evidence suggested that $\mathrm{Cq}$ might be efficacious as 5-nitroimidazole compounds in the treatment of giardiasis in lambs. This may be briefly explained with previous studies. $\mathrm{Cq}$ has been detected to have antigiardial activity invitro $(22,23)$. Gordts et al (22) tested 25 Giardia isolates and declared that more than a half of the Giardia isolates were very susceptible to $\mathrm{Cq}$ invitro. Similarly, Baveja et al (23) suggested the efficacy of $\mathrm{Cq}$ on in-vitro reducing ability against Giardia to attach and colonize.

In a comparative trial, 165 Cuban children with giardiasis were randomized to receive albendazole, $\mathrm{Cq}(10 \mathrm{mg} / \mathrm{kg}$ twice daily for 5 days) or tinidazole. Parasitological follow-up based on faecal samples collected 7 and 10 days after the completion of treatment revealed that tinidazole and $\mathrm{Cq}$ possessed similar efficacy ( $p>0.05$ ), curing $91 \%$ and $86 \%$ of the children treated, respectively, and significantly $(p<0.01)$ better than the albendazole, solely curing $62 \%$ of the children. In the latter study chloroquine appears to be a good alternative for the treatment of paediatric patients with giardiasis (24). Another trial comparing the efficacy and safety of chloroquine versus metronidazole in the treatment of children infected with $G$. duodenalis, faecal samples on days 3, 5 and 7 after treatment completion revealed that the frequency of cure was a little higher for $\mathrm{Cg}$ without statistical significance. The latter study suggested that $\mathrm{Cq}$, as an excellent alternative treatment for 5 days, was as efficacious as the recommended treatment with metronidazole, the gold standard in the treatment of giardiasis, in children infected with $\mathrm{G}$. duodenalis (25). The efficacy of $\mathrm{Cq}$ in sheep is comparable to those of aforementioned articles in humanbeing naturally infected with giardiasis. Similarly to what have been described above, Cq possessed a high efficacy in reduction of cyst excretion in contrast to the untreated control group in this study.

In the present study $\mathrm{Cq}$ treatment significantly reduced the cyst excretion calculated based on geometric or arithmetic means by $100 \%$ on days 7 and 10 after the start of the treatment, resulting in a significant reduction $(p<0.001)$ in cyst excretion in chloroquine treatment group. el presente ensayo clínico la cloroquina fue bien tolerada, no se evidenciaron efectos secundarios, por lo que no se necesitaron tratamientos o retiros. La evidencia disponible sugiere que la Cq podría ser tan eficaz como los compuestos 5-nitroimidazol en el tratamiento de la giardiasis en los corderos. Esto se explica brevemente con estudios anteriores. Se ha detectado que la $\mathrm{Cq}$ tiene actividad antigiardial in-vitro $(22,23)$. Gordts et al (22) ensayaron con 25 aislamientos de Giardia y declararon que más de la mitad de los aislamientos de Giardia fueron muy susceptibles a la $\mathrm{Cq}$ in-vitro. Del mismo modo Baveja et al (23) sugieren la eficacia de la Cq en la reducción de la capacidad in-vitro de la Giardia para fijarse y colonizar.

En un ensayo comparativo se seleccionaron aleatoriamente 165 niños cubanos con giardiasis para recibir albendazol, $\mathrm{Cq}(10 \mathrm{mg} / \mathrm{kg}$ dos veces al día durante 5 días) o tinidazol. Se realizó un seguimiento parasitológico con base en las muestras fecales recogidas 7 y 10 días después de la terminación del tratamiento, lo que reveló que el tinidazol y $\mathrm{Cq}$ poseen eficacia similar ( $p>0.05$ ), curando el $91 \%$ y el $86 \%$ de los niños tratados respectivamente y significativamente mejor $(p<0.01)$ que el albendazol, que curó solamente el $62 \%$ de los niños. El último estudio con cloroquina parece ser una buena alternativa para el tratamiento de pacientes pediátricos con giardiasis (24). En otro ensayo que compara la eficacia y seguridad de la cloroquina versus el metronidazol para el tratamiento de niños infectados con $G$. duodenalis, las muestras fecales tomadas a los 3, 5 y 7 días después de finalizar el tratamiento revelaron que la frecuencia de curación fue un poco más alta para $\mathrm{Cq}$ sin significancia estadística. Este último estudio sugiere que la $\mathrm{Cq}$ por 5 días es un excelente tratamiento alternativo tan eficaz como el tratamiento recomendado con metronidazole, el estándar de oro en el tratamiento contra la giardiasis en niños infectados con $g$. duodenalis (25). La eficacia de la Cq en ovejas es comparable a las de los artículos mencionados en seres humanos infectados naturalmente con giardiasis. Similar a lo descrito anteriormente, la $\mathrm{Cq}$ tuvo una alta eficacia en la reducción de la excreción de quistes en contraste con el grupo de control no tratado en este estudio.

En el presente estudio el tratamiento con Cq redujo significativamente la excreción de quistes según cálculos basados $100 \%$ en las medias geométrica o aritmética a los 7 y 10 días después de iniciado el tratamiento, dando como resultado una reducción significativa $(p<0.001)$ de la excreción de quistes en el grupo tratado con cloroquina. 
Given the efficacy of $\mathrm{Cq}$ (as it resulted in a significantly decreased cyst excretion) for treatment of naturally occuring giardiasis among Merino and Sakiz lambs involved in the present study, the usage of this of drug should be encouraged. The high cyst reducing activity of $\mathrm{Cq}$ against giardiasis may be of beneficial in a clinical setting where a specific diagnosis is impossible likewise livestock field condition. The case of availability of the latter inexpensive drug, the cost (only 0.85 dollars per a lamb for 5 days therapy) and the easily availability for market opportunity have been significant clues for usage of this antiparasitic drug against giardiasis in lambs.
Dada la eficacia de la Cq (como resultado de una reducción significativa en la excreción de quistes) en el tratamiento de giardiasis de origen natural en los corderos Merino y Sakiz involucrados en el presente estudio, se recomienda el uso de este medicamento. La alta reducción de la actividad quística de la $\mathrm{Cq}$ contra la giardiasis puede ser benéfica en un entorno clínico donde no es posible tener un diagnóstico específico al igual que la condición del ganado en campo. El caso de la disponibilidad del último medicamento barato (sólo 0,85 dólares por cordero para la terapia de 5 días) y el fácil acceso al mercado han sido significativamente claves para el uso de este fármaco antiparasitario contra la giardiasis en los corderos.

\section{REFERENCES}

1. Castro-Hermida JA, Pors I, Poupin B, AresMazás E, Chartier C. Prevalence of Giardia duodenalis and Cryptosporidium parvum in goat kids in western France. Small Rumin Res 2005; 56:259-264.

2. Fayer R, Santín M, Trout JM, Greiner E. Prevalence of species and genotypes of Cryptosporidium found in 1-2-year-old dairy cattle in the eastern United States. Vet Parasitol 2006; 135:105-112.

3. Xiao L. Giardia infection in farm animals Parasitol. Today 1994; 10:436-438.

4. Thompson R.C. Thompson Giardiasis as a re-emerging infectious disease and its zoonotic potential. Int J Parasitol 2000; 30:1259-1267.

5. Hunter PR, Thompson RCA. The zoonotic transmission of Giardia and Cryptosporidium. Int J Parasitol 2005; 35:1181-1190.

6. Ozmen O, Yukari BA, Haligur M, Sahinduran S. Observations and immunohistochemical detection of coronavirus, cryptosporidium parvum and giardia intestinalis in neonatal diarrhoea in lambs and kids. Schweiz Arch Tierheilkd 2006; 148:357-364.

7. Ozdal N, Tanritanir P, Goz Y, Deger S, Kozat S. Parasitic protozoans (Eimeria, Giardia, and Cryptosporidium) in lambs with diarrhoea in the Van Province (Turkey). Bull Vet Inst Pulawy 2009; 53:47-51.
8. Robertson LJ. Giardia and Cryptosporidium infections in sheep and goats: A review of the potential for transmission to humans via environmental contamination. Epidemiol Infect 2009; 137:913-921.

9. Geurden T, Vercruysse J, Claerebout E. Is Giardia a significant pathogen in production animals?. Exp Parasitol 2009; 124:98-106.

10. Geurden T, Pohleb H, Sarrea C, Dreesena L, Vercruyssea J, Claerebouta E. The efficacy of a treatment with fenbendazole against an experimental Giardia duodenalis infection in lambs. Small Rum Res 2011; 96(2-3):211215.

11. Aloisio F, Filippini $G$, Antenucci $P$, Lepri $E$, Pezzotti G, Cacciò MS, et al. Severe weight loss in lambs infected with Giardia duodenalis assemblage. B Vet Parasitol 2006; 142(12):154-158.

12. Mohammed BA. Efficacy of albendazole with two different doses for the treatment of giardiasis in domestic ruminants. Iraq $\mathrm{J}$ Vet Sci 2006; 20(2):265-282.

13. Alıç Ural D, Ayan A, Aysul N, Balıkçı C, Ural K. Secnidazol Treatment to Improve Milk Yield in Sheep with Giardiasis. Atatürk Üniversitesi Vet. Bil. Derg. 2014; 9(2): 74-82. 
14. Ural K, Aysul N, Voyvoda H, Ulutas B, Aldemir OS, Eren H. Single dose of secnidazole treatment against naturally occuring Giardia duodenalis infection in Sakiz lambs. Rev MVZ Cordoba $2014 ; 19(1): 4023-4032$.

15. Albay MK, Sahinduran S, Adanir R, Yukari BA, Kose O. Efficacy of albendazole and two different doses of paromomycin for treatment of naturally occurring giardia infection in lambs. Kafkas Univ Vet Fak Derg 2011; 17:1021-1024.

16. Escobedo AA, Cimerman S. Giardiasis: A pharmacotherapy review. Expert Opin Pharmacother 2007; 8:1885-1902.

17. Pérez MA, Cortés LJ, Guerra AP, Knudson A, Usta C, Nicholls RS. Efficacy of the amodiaquine + sulfadoxine-pyrimethamine combination and of chloroquine for the treatment of malaria in Córdoba, Colombia, 2006. Biomedica 2008; 28:148-159.

18. van Tuyl LH, Lems WF, Voskuyl AE, Kerstens PJ, Garnero P, Dijkmans BA. Tight control and intensified COBRA combination treatment in early rheumatoid arthritis: 90\% remission in a pilot trial. Ann Rheum Dis 2008; 67:1574-1577.

19. Egan TJ, Ncokazi KK. Quinoline antimalarials decrease the rate of $\beta$-hematin formation. J Inorg Biochem 2005; 99: 1532-1539.
20. Wilson JM, Hankerson FC. Evaluation of an inhouse rapid ELISA test for detection of Giardia in domestic sheep (Ovis aries). JAALAS 2009; 49(6):809-813.

21. Escobedo AA, Cañete R, Gonzalez ME, Pareja A, Cimerman S, Almirall P. A randomized trial comparing mebendazole and secnidazole for the treatment of giardiasis. Ann Trop Med Parasitol 2003; 97(5):499-504.

22. Gordts B, Hemelhof W, Asselman C, Butzler J. In vitro susceptibilities of 25 Giardia lamblia isolates of human origin to six commonly used anti-protozoal agents. Antimicrob Agents Chemother 1985; 28:378-80.

23. Baveja UK, Bathia VN, Warhurst DC. Giardia lamblia: in-vitro sensitivity to some chemotherapeutic agents. J Communicable Dis $1998 ; 30: 79-84$.

24. Escobedo $A A$, Núñez FA, Moreira I, Vega E, Pareja A, Almirall P. Comparison of chloroquine, albendazole and tinidazole in the treatment of children with giardiasis. Ann Trop Med Parasitol 2003; 97(4):367-371.

25. Cañete R, Rivas DE, Escobedo AA, González $M E$, Almirall $P$, Brito KA. randomized, controlled, open-label trial evaluating the efficacy and safety of chloroquine in the treatment of giardiasis in children. West Indian Med J 2010; 59(6):607-611. 